\title{
PENGINTEGRASIAN MEDIA PEMBELAJARAN VIRTUAL BERBASIS GEOGEBRA UNTUK MENINGKATKAN KETERLIBATAN DAN PEMAHAMAN KONSEP MATEMATIKA SISWA KELAS VIII SMPN 6 SINGARAJA
}

\author{
Gede Suweken \\ Jurusan Pendidikan Matematika, FMIPA - Undiksha \\ e-mail: gdsuweken5@gmail.com
}

\begin{abstract}
Abstrak
Penelitian ini adalah penelitian tindakan kelas yang dimaksudkan untuk meningkatkan motivasi dan pemahaman siswa terhadap konsep-konsep matematika. Subjek penelitiannya adalah siswa kelas VIII A SMP Negeri 6 Singaraja yang jumlahnya 31 orang. Adapun tindakan yang diberikan kepada siswa adalah berupa penggunaan media pembelajaran berbasis Geogebra dalam pembelajaran matematika. Tindakan yang diberikan berhasil meningkatkan prestasi belajar siswa dari 55,6 menjadi 71,2. Tindakan juga berhasil meningkatkan motivasi belajar siswa dalam pembelajaran yang tercermin dari keaktifan mereka selama pembelajaran berlangsung.
\end{abstract}

Kata Kunci: media pembelajaran berbasis Geogebra, eksplorasi matematika, Prestasi belajar, motivasi, keterlibatan.

\begin{abstract}
The research is is a classroom action research which is caried out in order to improve students' learning motivation and students' understanding of the mathematical concepts. The subject is students of SMP Negeri 6 Singaraja class VIII A which is consisted of 31 students. Treatment being investigated is the use of interactive learning mediabased on Geogebra in learning mathematics. It is found that the proposed treatment has successfully increase students' achievent on mathematical test from 55,6 to 71,2 . The treatment has also successfull in improving students learning motivation, which is evidenced by their active involvement during the learning process.
\end{abstract}

Keywords: mathematics learning media based on Geogebra, mathematics, Exploration, learning achievement, motivation, engagement.

\section{PENDAHULUAN}

Dunia pendidikan, khususnya pendidikan matematika, mendapat perhatian yang sangat serius berkaitan dengan tuntutan untuk menghasilkan sumber daya manusia yang berkualitas serta mampu bersaing di era global. Matematika merupakan salah satu ilmu yang berperan penting dalam perkembangan ilmu pengetahuan dan teknologi sehingga mata pelajaran matematika diberikan disetiap jenjang pendidikan baik pendidikan dasar maupun menengah.

Mengingat pentingnya peranan matematika dalam segala aspek kehidupan, berbagai upaya telah dilakukan pemerintah untuk meningkatkan mutu pendidikan seperti program pening-katan kualitas guru melalui seminar dan penataran, peningkatan kualitas dan kuantitas sarana dan prasarana belajar mengajar serta perubahan kurikulum dari kurikulum 1994 menjadi kurikulum berbasis kompetensi (KBK) dan terakhir disempurnakan dengan berlakunya kurikulum tingkat satuan pendidikan (KTSP). Pelatihan-pelatihan tentang penelitian tindakan kelas (PTK) juga dilaksanakan untuk menggugah guru memperbaiki kualitas pembelajaran mereka di kelas masing-masing.

Semestinya dengan usaha-usaha yang telah dilakukan di atas kualitas pembelajaran dan hasil belajar siswa meningkat. Namun kenyataannya hasil belajar siswa terutama pada mata pelajaran matematika tetap saja rendah. Pada semester ganjil tahun 2011 yang lalu, 
misalnya, data dari Bagian Kurikulum SMPN

matematika siswa kelas VIII sebagai berikut:

6 Singaraja menunjukkan hasil belajar

Tabel 1: Data Hasil Belajar Matematika Semester Ganjil 2011

\begin{tabular}{|c|c|c|}
\hline Kelas & Rata-rata Kelas & Ketuntasan Kelas \\
\hline VIII A1 & 82,25 & $83,33 \%$ \\
\hline VIII A2 & 45,65 & $15,38 \%$ \\
\hline VIII B1 & 65,38 & $46,88 \%$ \\
\hline VIII B2 & 40,7 & $0 \%$ \\
\hline
\end{tabular}

Hasil belajar matematika yang rendah bukan saja terjadi pada kelas-kelas biasa, tetapi juga pada kelas VIII yang merupakan kelas unggulan dengan siswa-siswa terbaik di tingkat yang bersangkutan. Kemungkinan salah satu penyebab dari tingkat penguasaan matematika yang rendah tersebut adalah kurang bervariasinya situasi pembelajaran. Pembelajaran yang monoton menerapkan suatu model yang dianggap jitu, tetap akan mengurangi minat belajar. Kurangnya minat belajar akan berpengaruh tingkat ketuntasan siswa dalam menguasai materi yang dipelajari. Karena sifat matematika yang hierarkis, penguasaan suatu konsep yang tidak tuntas ini secara akumulatif akan menimbulkan masalah yang semakin besar. Jika siswa gagal dalam konsep tertentu, mungkin bukan karena konsep tersebut sulit, melainkan karena ia tidak menguasai konsep yang mendasarinya. Dalam kondisi seperti ini, latihan soal-soal hanya akan menambah frustasi siswa. Latihan soal-soal hanya akan bermanfaat, baik bagi pemantapan konsep yang telah dipelajari maupun pengembangannya, jika konsep dasarnya telah dikuasai siswa.

Pembelajaran yang bervariasi ini, semakin diperlukan jika diingat siswa masukan dari SMPN 6 ini. Secara umum, masukan siswa dari sekolah ini bukanlah yang terbaik terutama dari segi akademik. Calon-calon siswa yang terbaik biasanya terserap di sekolah lain yang lebih vaporit. Keadaan inilah yang mungkin menyebabkan motivasi belajar siswa masih rendah dan perlu ditingkatkan.
Pendekatan baru dalam pembelajaran matematika menggunakan apa yang disebut dengan pendekatan aturan 3 (the rule of three), yakni sedapat mungkin konsep-konsep matematika harus disajikan dengan menggunakan tiga pendekatan yaitu analitik, numerik, dan visual. Tujuannya adalah agar konsepkonsep matematika bisa dilihat dari berbagai sudut dan dengan demikian memperbesar peluang konsep tersebut bisa dimengerti oleh siswa yang karakteristiknya bervariasi. Sebagai contoh adalah pembelajaran konsep gradien suatu garis lurus. Secara analitik, tentu saja gradien garis lurus yang melalui titik-titik $\left(\mathrm{x}_{1}, \mathrm{y}_{1}\right)$ dan $\left(\mathrm{x}_{2}, \mathrm{y}_{2}\right)$ adalah harga dari:

$$
\frac{\mathrm{y}_{1}-\mathrm{y}_{2}}{\mathrm{x}_{1}-\mathrm{x}_{2}}
$$

Jika hanya ini yang disampaikan ke siswa, maka mereka akan menghafal saja rumus tersebut. Tetapi, jika gradien juga disajikan secara visual, maka kemungkinan besar rumus tersebut akan dapat dimengerti dengan lebih baik oleh lebih banyak siswa.

Demikian juga halnya dengan konsep kesejajaran, ketegaklurusan, dan keberpotongan antara dua garis lurus akan lebih mudah dimengerti jika disajikan secara visual. Aspek visual sejauh ini masih sangat jarang dimanfaatkan dalam pembelajaran matematika. Dahulu, penggunaan pendekatan visual ini dalam pembelajaran matematika tentu saja memakan banyak waktu, karena setiap saat guru atau siswa harus menggambar grafik, diagram atau ilustrasi. Namun kini dengan adanya komputer yang semakin canggih dan 
semakin murah, tidak ada alasan lagi untuk tidak melibatkan aspek visual dalam pembelajaran. Di SMPN 6 Singaraja, komputer sudah tersedia secara memadai, namun belum dimanfaatkan secara maksimal dalam pembelajaran matematika. Hal ini disebabkan karena kurangnya pengetahuan guru dalam membuat program-program sederhana yang bisa dimanfaatkan dalam pembelajaran. Penggunaan komputer dalam pembelajaran diharapkan juga akan mampu meningkatkan motivasi belajar siswa. Hal ini disebabkan karena siswa akan belajar secara aktif melalui interaksi langsung dengan alat tersebut, melakukan eksplorasi terhadap konsep yang sedang dipelajari, dan bereksperimen dengan jalan mengubahubah parameter dalam suatu model (persamaan) matematika. Sementara itu feedback yang diberikan komputer baik dalam bentuk angka maupun grafik dan animasi bersifat sangat segera, suatu hal yang sulit diperoleh sebelumnya dengan tanpa komputer. Inilah yang menyebabkan orang-orang berpikir mengapa pembelajaran berbantuan komputer kemungkinan besar akan dapat meningkatkan motivasi belajar dan pada gilirannya meningkatkan hasil belajar. Beberapa hasil riset memang mendukung prediksi ini (Akour, Mohammed Ali, 2005, Smith, David A., 2001). Dalam tulisannya, Kamaludin Ahmad (2001) merinci lebih jauh mengapa pembelajaran berbantuan komputer bisa sangat berkesan bagi siswa.

Program komputer yang kini tersedia secara luas dan gratis di internet adalah GeoGebra. Program ini dirancang sedemikian rupa sehingga memenuhi prinsip aturan tiga pembelajaran seperti yang telah disebutkan di atas. Menggunakannya pun relatif mudah, sehingga hanya dengan pelatihan minimal guru akan bisa menggunakannya. Kendala terbesar yang secara potensial muncul dalam pengintegrasian GeoGebra sebagai alat bantu dalam pembelajaran matematika adalah bagaimana merancang media pembelajaran yang baik dan memanfaatkan GeoGebra untuk mewujudkannya.

Hasil-hasil penelitian menunjukkan keberhasilan pemanfaatan media pembelajaran virtual pada umumnya dan GeoGebra pada khususnya dalam pembelajaran matematika. Moyer Packenham, P. dan Suh, J. (2012) menunjukkan bagaimana virtual manipulatives meningkatkan hasil belajar siswa kelas 5 SD. Sedangkan yang menyangkut pemanfaatan GeoGebra dalam pembelajaran matematika yang menyangkut pemecahan masalah telah dilakukan oleh Cengel, M. dan Karadag, Z. (2010), yang menyangkut multirepresentasi telah dilakukan Stojanovska, L.F. dan Stojanovski, V., (2010), dan yang terkait denganpembuatan konjektur dan pembuktian telah dilakukan oleh Aksoy, Y. et.all., (2010).

Berdasarkan atas pemikiran di atas itulah penelitian berjudul: "Pengintegrasian Media Pembelajaran Virtual Berbasis GeoGebra Untuk Meningkatkan Keterlibatan dan Pemahaman Konsep Matematika Siswa Kelas VIII SMPN 6 Singaraja"diusulkan untuk mengatasi permasalahan pembelajaran yang terjadi.

Seperti yang telah disinggung di atas, maka dapat dirumuskan permasalahan sebagai berikut:

1) Apakah pengintegrasian media pembelajaran virtual berbasis GeoGebra pada proses pembelajaran dapat meningkatkan keterlibatan siswa kelas VIII SMPN 6 Singaraja dalam belajar matematika,

2) Apakah pengintegrasian media pembelajaran virtual berbasis GeoGebra pada proses pembelajaran matematika dapat meningkatkan pemahaman konsep matematika siswa kelas VIII SMPN 6 Singaraja. terhadap materi persamaan garis lurus, dan

3) Apakah kendala-kendala yang terjadi dalam mengintegrasikan media 
pembelajaran virtual berbasis GeoGebra ke dalam pembelajaran matematika.

\section{METODE}

Penelitian ini merupakan penelitian tindakan kelas (PTK) dengan subjek penelitian siswa kelas VIII B4 SMP Negeri 6 Singaraja Tahun Ajaran 2011/2012. Variabel bebas dari penelitian ini adalah berupa pemberian tindakan pembelajaran matematika berbantuan media pembelajaran berbasis Geogebra, sedangkan variable terikatnya adalah pemahaman konsep siswa yang dicerminkan dengan skor tes yang mereka peroleh dan motivasi belajar mereka sebagai akibat dari pemberian tindakan. Tingkat pemahaman siswa terhadap konsep-konsep matematika (Relasi dan Fungsi, Persamaan Garis Lurus, dan Teorema Pythagoras) diukur dengan menggunakan tes hasil belajar bebentuk uraian, sedangkan motivasi diukur dengan menggunakan kuesioner dengan 5 kategori (skala Likert). Selanjutnya skor tes yang diperoleh siswa dianalisis dengan menggunakan statistic deskriptif. Meningkatnya pemahaman siswa terhadap konsep-konsep matematika sebagai akibat dari pemberian tindakan dideteksi dari dari adanya peningkatan rata-rata skor tes dari sklus ke siklus.

Untuk mengetahui motivasi belajar siswa sebagai akibat dari pemberian tindakan dideteksi melalui tingkat motivasi siswa yang diperoleh dari analisis data kuesioner. Data kuesioner ini diklasifikasikan ke dalam 5 tingkatan; sangat kurang, kurang, sedang, tinggi, dan sangat tinggi.

\section{HASIL DAN PEMBAHASAN}

\section{A. Hasil Pengkajian Terhadap Materi Pelajaran \\ Melalui \\ refleksi terhadap}

pembelajaran konsep-konsep matematika kelas VIII, khususnya konsep-konsep mengenai Relasi dan Fungsi, Garis Lurus, dan Teorema Pythagoras diperoleh kesimpulan bahwa siswa umumnya:
1. Mengalami kesulitan dalam membedakan konsep relasi dan fungsi sehingga perlu dicarikan jalan lain dalam pembelajarannya,

2. Siswa mengalami kesulitan dalam memberikan makna terhadap gradien dan konstanta suatu garis lurus. Hal ini bisa dipahami karena memang sebelumnya persamaan garis hanya diajarkan secara analitik, pendekatan visual masih belum digunakan secara optimal dalam pembelajaran materi ini,

3. Siswa mengalami kesulitan dalam membayangkan posisi/kedudukan grafik dua garis,

4. Siswa mengalami kesulitan dalam mengaplikasikan konsep-konsep linearitas da-lam kehidupan sehari-hari atau bidang studi lain,

5. Dikasi informasi langsung tentang Rumus Pythagoras, sehingga pembelajaran bersi-fat hapalan. Siswa tidak dilibatkan dalam memaknai dan menurunkan Rumus Pythagoras tersebut,

6. Belum mampu mengembang-kan materi Teorema Pytha-goras. Misalnya mereka belum mengetahui bahwa persegi pada sisi-sisi segitiga siku-siku bisa diganti dengan segi banyak beraturan lainnya, termasuk setengah lingkaran.

Untuk mengatasi kendala-kendala di atas dan untuk meningkatkan keterlibatan siswa dalam pembelajaran, peneliti bersama-sama gurumerancang media pembelajaran (mathlet) yang eksploratif berbasis Geogebra. Untuk keperluan pembuatan mathlet ini, pelatihan telah dilakukan selama beberapa hari dengan materi tentang penggunaan Geogebra untuk membuat grafik, membuat bangun-bangun geometri datar, dan materi tentang bagaimana membuat mathlet yang baik dan eksploratif. Setelah pelatihan ini, maka peneliti bersama-sama guru mengembangkan mathlet yang diperlukan untuk pembelajaran konsep Relasi dan Fungsi, Garis Lurus, dan Teorema Pythagoras. Berikut adalah beberapa 
mathlet yang berhasil kami kembangkan. Mathlet-mathlet tersebut sebenarnya bersifat dinamik, namun karena laporan ini bersifat tekstual, maka kedinamisan dari mathletmathlet tersebut tidak bisa ditunjukkan.
Pembaca yang berminat dapat mengeksplorasi mathlet-mathlet yang dihasilkan tersebut dengan mengases CD yang merupakan bagian tidak terpisahkan dari laporan ini.

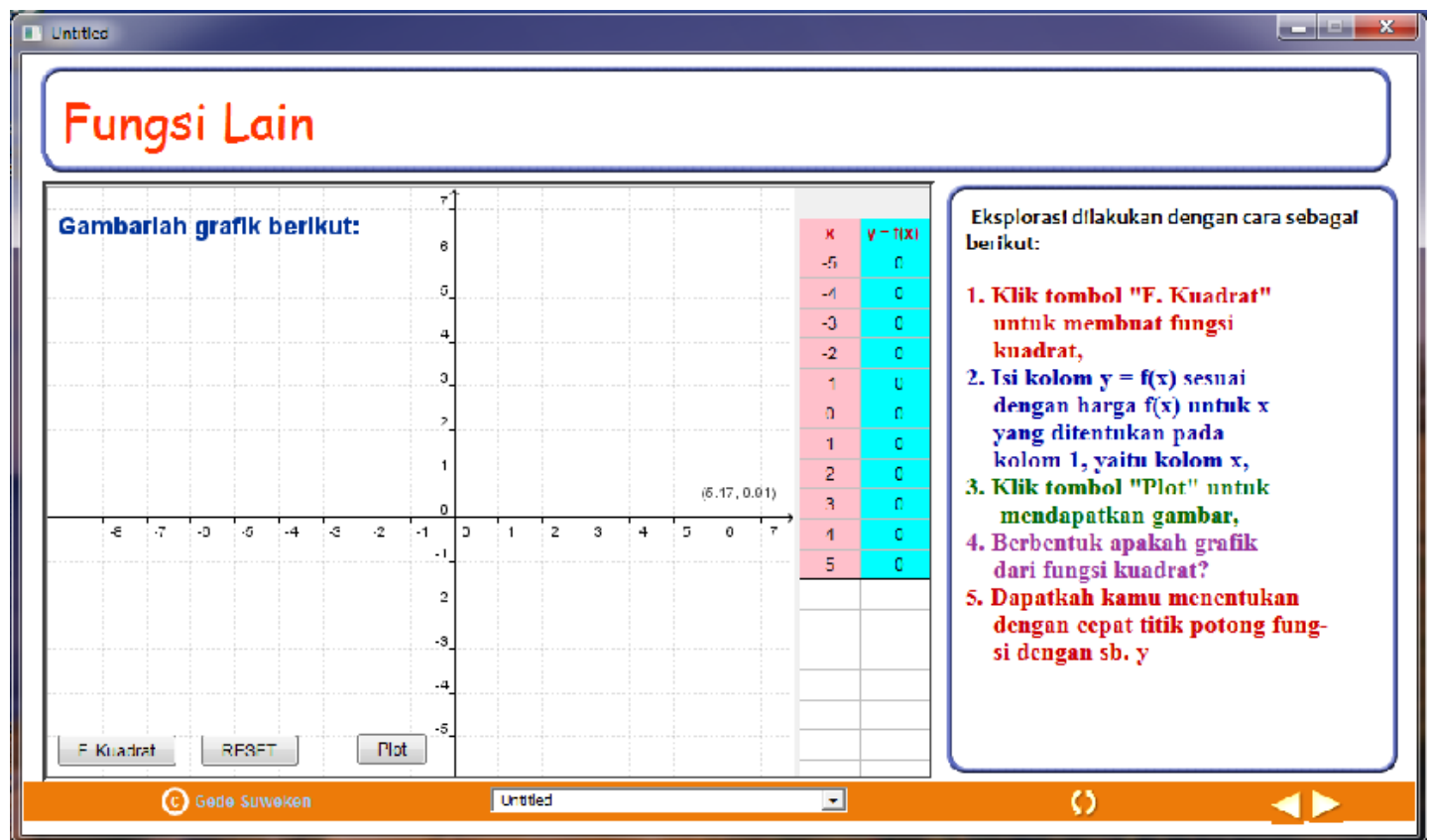

Gambar 1: Mathlet Relasi dan Fungsi

Mathlet yang pertama adalah mathlet tentang fungsi linear. Dengam mathlet ini, siswa bisa melakukan eksplorasi tentang fungsi linear seperti misalnya bagaimana menentukan bayangan dari suatu nilai atas fungsi yang digunakan, bagaimana menggambar posisi titik $(x, y)$ pada sistem koordinat kartesius, dan akhirnya siswa bisa melihat berbentuk apakah grafik dari fungsi linear tersebut. Mathlet juga memberikan kesempatan kepada siswa untuk melihat grafik dari fungsi-fungsi lain selain fungsi linear.
Mathlet berikutnya yang masih merupakan bagian dari mathlet fungsi adalah mathlet tentang domain dan range fungsi. Dengan mathlet ini siswa bisa mengeksplorasi range dari suatu sekumpulan nilai yang dikenai fungsi tertentu. Dengan mathlet siswa juga bisa melihat bahwa range dari suatu fungsi kuadrat bisa mencapai niai maksimum atau minimum yang tidak terletak pada ujungujung dari interval domainnya. 


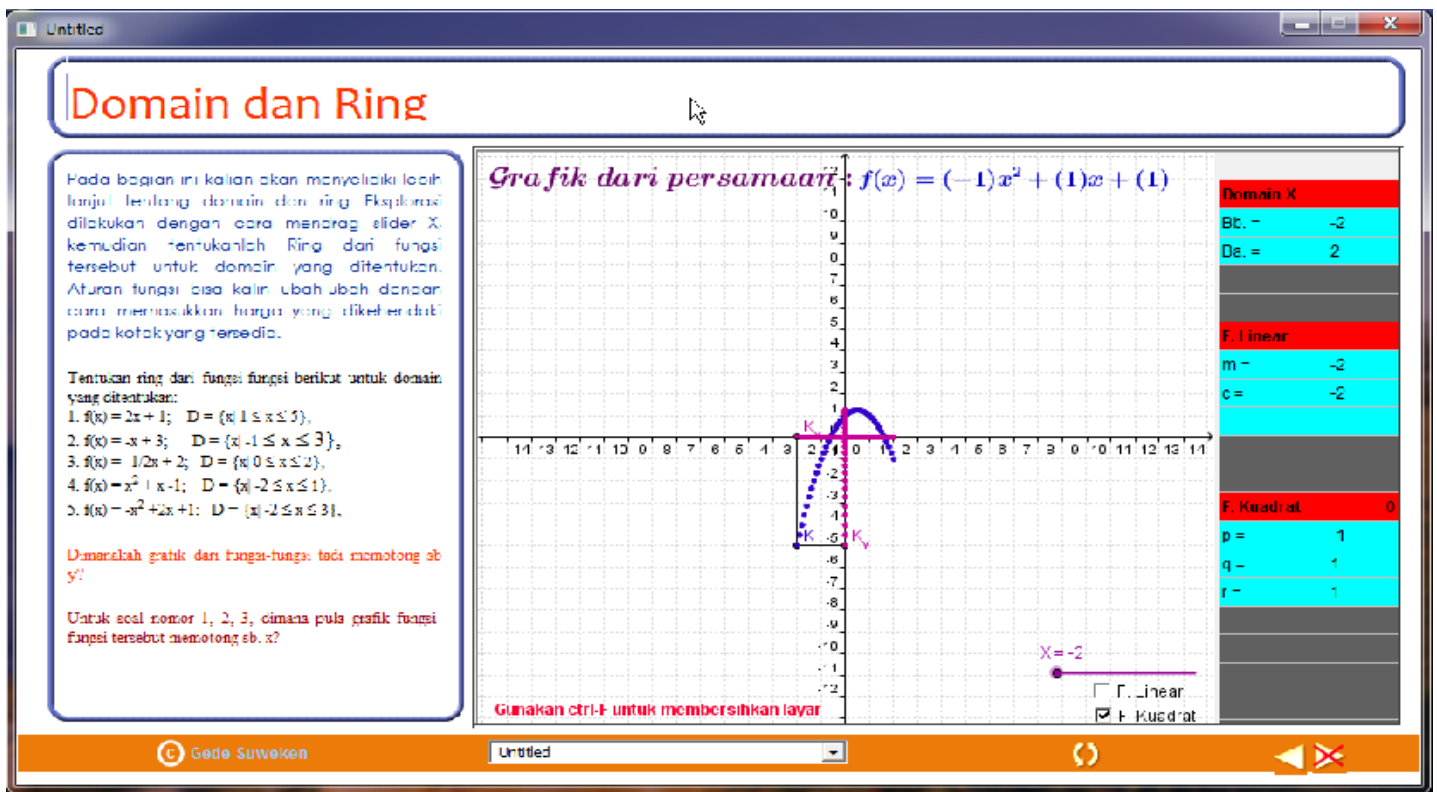

\section{Gambar 2: Mathlet Domain dan Range Fungsi}

Mathlet terakhir yang berhasil dibuat adalah Mathlet Pythagoras. Dengan mathlet Pythagoras, selain dapat mengekpslorasi dan menemukan rumus Pythagoras baik melalui penggunaan persegi pada sisi-sisi segitiga siku-siku maupun melalui

penggunaan bangun-bangun geometrik yang lain, siswa juga bisa mengeksplorasi lebih jauh tentang keterkaitan antar konsep pada matematika seperti yang ditunjukkan oleh mathlet berikut ini.

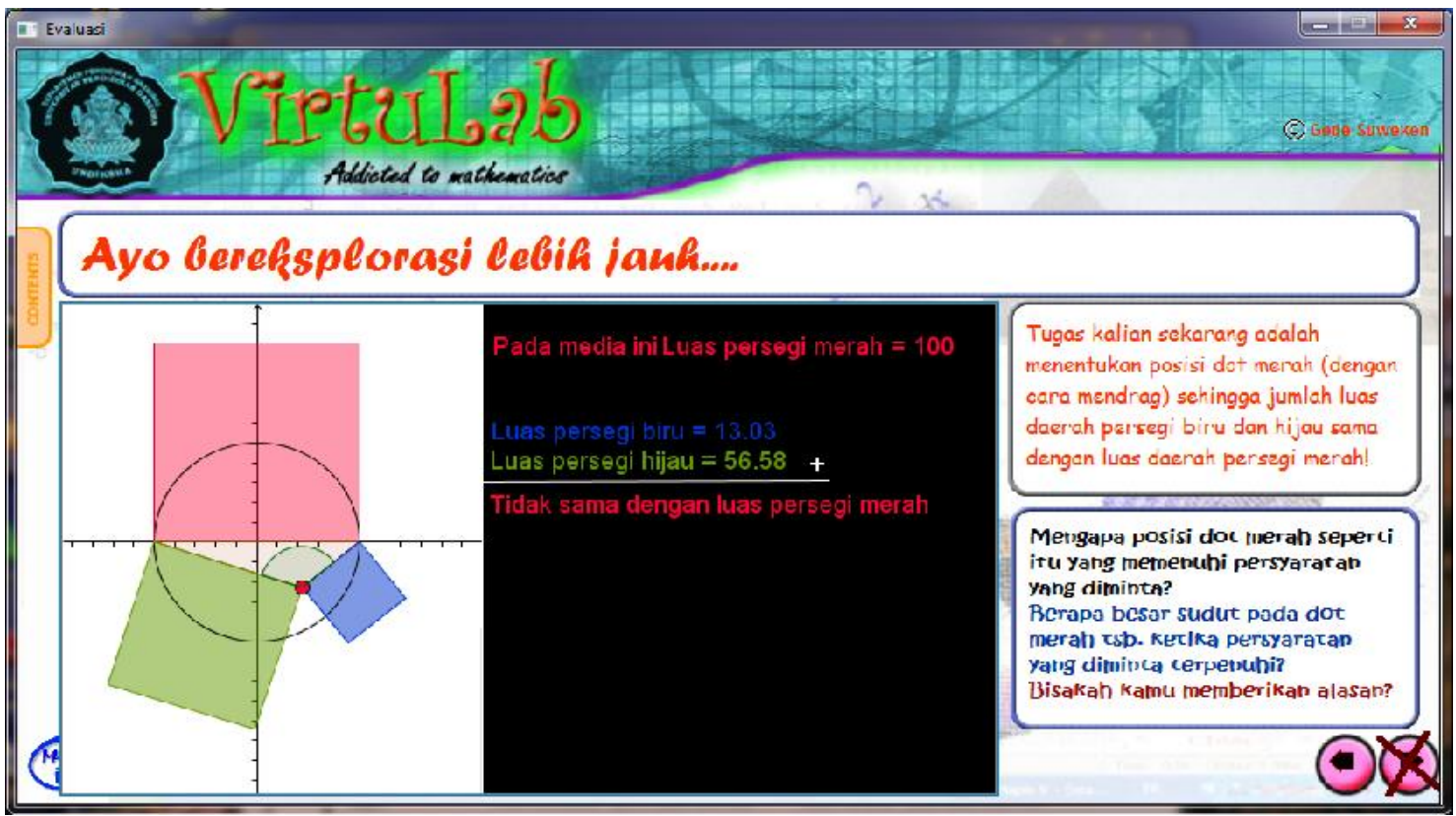

Gambar 3: Problem Solving dalam Teorema Pythagoras 


\section{HASIL DAN PEMBAHASAN SETIAP SIKLUS}

Seperti yang telah diuraikan pada bagian prosedur penelitian, pada siklus I pembelajaran matematika dibantu dengan penggunaan komputer. Sedapat mungkin, pembelajaranmatematika diselenggarakan dengan menggunakan pendekatan aturan tiga (the rule of three), yaitu analitik, numerik, dan visual.Setiap dua minggu sekali juga diadakan kegiatan lab.

Dalam kegiatan ini, siswa mendapatkan kesempatan lebih banyak lagi untuk melihat dan mmengeksplorasi konsep-konsep matematika secara visual.

Pertemuan pertama diisi dengan informasi bahwa pembelajaran akan dilengkapi dengan penggunaan mathlet, yaitu program komputer yang didisain khusus untuk mengeksplorasi suatu konsep tertentu. Juga diinformasikan kepada siswa bahwa pembelajaran matematika akan diselenggarakan dengan cara yang sedikit berbeda dari biasanya, yaitu dengan eksplorasi dan eksperimen. Melalui eksplorasi siswa diharapkan akan bisa memaknai konsep-konsep matematika dengan lebih baik, bisa menemukan polapola matematika secara informal terlebih dahulu sebelum pada akhirnya diformalkan melalui diskusi, elaborasi, maupun konfirmasi.

Materi pada siklus I ini adalah Relasi dan Fungsi. Pada materi ini, penekanan terutama diberikan pada Relasi dan Fungsi Linear, karena materi kelanjutan dari materi relasi dan fungsi ini adalah Persamaan Garis Lurus yang sebenarnya tidak lain adalah Fungsi Linear. Mathlet Relasi dan Fungsi yang pertama, terutama digunakan untuk mengeksplorasi bagaimana menentukan titik-titik kordinat yang dibentuk oleh fungsi linear, bentuk grafik dari fungsi linear, dimana grafik memotong sumbusumbu koordinat, dan sebagai pemanding, pada mathlet berikutnya juga disertakan Fungsi Kuadrat yang grafiknya ternyata bukan merupakan garis lurus.
Terkait dengan aplikasi dari fungsi linear, terdapat satu mathlet tentang konversi suhu dari, baik itu konversi dari Celcius ke Reaumur, maupun dari Celcius ke Fahrenheit. Misalnya benda dengan suhu $10^{\circ} \mathrm{C}$ ternyata memiliki suhu yang sama dengan $8^{\circ} \mathrm{R}$, dan benda dengan suhu $20^{\circ} \mathrm{C}$ sama dengan benda yang suhunya $16^{\circ} \mathrm{R}$. Jika pasangan-pasangan suhu ini digambar grafiknya ternyata menghasilkan garis lurus, sehingga hubungan antara derajat Celcius dan derajat Reaumur ternyata adalah hubungan linear. Begitu pun halnya hubungan antara derajat Celcius dan derajat Fahrenheit, serta antara Reaumur dan Fahrenheit. Dengan grafik siswa akan bisa melihat dan menentukan besarnya suhu dalam derajat tertentu jika suhunya dalam derajat yang lain diberikan. Pemahaman suatu konsep matematika dengan pendekatan visual adalah pendekatan yang belum banyak digunakan sejauh ini, walaupun sebenarnya pendekatan ini sangat sering digunakan oleh para matematisi. Dalam menggunakan mathletmathlet di atas, siswa dibimbing oleh suatu LKS, baik yang menyatu dengan mathlet itu sendiri maupun LKS dalam bentuk cetakan.

Sebagai hasil dari perlakuan yang diberikan, rata-rata skor prestasi belajar yang diperoleh siswa pada akhir siklus I adalah 55,6. Hasil ini belum memenuhi kreteria yang ditetapkan sekolah yaitu 68 . Kendala utama yang dialami pada siklus I ini adalah belum terbiasanya siswa melakukan eksplorasi dan menemukan konsep-konsep matematika melalui eksplorasi tersebut. Biasanya mereka menerima begitu saja konsep dari guru, namun kini mereka harus membangun sendiri konsep tersebut. Walaupun perlakuan yang diberikan sesuai dengan paradigma baru pembelajaran matematika, namun perubahan pendekatan pembelajaran yang begitu tiba-tiba tidak berhasil meningkatkan prestasi belajar mereka.

Pada siklus II konsep matematika yang hendak dibelajarkan berlanjut menjadi Persamaan Garis Lurus dan Grafiknya. 
Selain dengan bantuan mathlet, pembelajaran juga dilaksanakan dengan mengimplementasikan kooperatif tipe thinkpair-share. Model ini digunakan untuk memberikan kesempatan kepada para siswa melakukan diskusi dengan temannya. Dengan diskusi ini diharapkan konstruksi konsep-konsep matematika yang mereka lakukan akan menjadi lebih baik dan benar.

$$
\text { Dalam pembelajaran guru }
$$

senantiasa meminta siswa agar memprediksi apa hasil dari suatu eksplorasi dan memikirkan alasan mengapa hasilnya seperti itu. Juga, agar diskusi berjalan dengan baik, setiap siswa hendaknya bias memberi dan menerima pendapat teman, dan berbicara dengan sopan-santun agar tidak ada siswa yang tersinggung. Siswa diharapkan ridak mendominasi teman lain dalam satu kelompok.

Dengan perlakuan seperti ini, ratarata skor prestasi belajar berhasil ditingkatkan menjadi 63,2 dari 55,6 pada siklus I. Rata-rata ini masih belum mencapai SKM sebesar 68. Walaupun prestasi belajar masih belum mencapai SKM yang diharapkan, jika dilihat proses belajar yang terjadi, dengan jelas teramati bahwa keterlibatan siswa dalam pembelajaran sangat intens. Diskusi siswa berjalan dengan sangat aktif dan berisi materi yang dibahas saat itu.

Kendala yang dihadapi pada siklus ini adalah kendala bahasa. Banyak katakata, istilah-istilah, atau kalimat-kalimat pada mathlet yang tidak dimengerti siswa. Hal ini kemungkinan disebabkan oleh terlalu sedikitnya arahan yang diberikan guru sehingga siswa mengalami kesulitan memahami mathlet. Peneliti dan guru memang menghadapi suatu dilemma dalam hal ini. Jika arahan diberikan terlalu banyak, maka tentu saja ruang yang tersisa bagi siswa untuk bereksplorasi dan berkreasi sangat sedikit. Namun, jika arahan diberikan terlalu sedikit, maka mereka menjadi kebingunan dan kesulitan dalam melakukan eksplorasi dan mendapatkan hasil yang diharapkan.
Pada siklus ini, petunjuk dan arahan pada mathlet dibuat secara lebih detail sehingga lebih jelas bagi siswa mengenai apa yang harus dicapai dan bagaimana mencapainya.

Materi pelajaran pada siklus III adalah Teorema Pythagoras. Teorema Pythagoras yang biasa, yakni yang menggunakan persegi pada sisi-sisi segitiga siku-siku untuk menemukan rumus $c^{2}=a^{2}+$ $\mathrm{b}^{2}$ dengan $\mathrm{c}$ adalah sisi miring dan $\mathrm{a}$ dan $\mathrm{b}$ adalah dua sisi yang lain, sebenarnya sudah mereka pelajari di Sekolah Dasar. Namun jika persegi tersebut diganti dengan benda lain, ternyata mereka belum pernah memikirkannya sama sekali. Dalam hal ini persegi tersebut diganti dengan setengah lingkaran, agar proses eksplorasinya tidak berkepanjangan. Jika digunakan benda yang lain, perhitungannya menjadi berkepanjangan, dan kami (guru dan peneliti) agak takut bahwa perhitungan yang berkepanjangan seperti ini akan membingungkan dan menjauhkan siswa dari konsep yang harus dipelajari.

Utamnya pada mathlet terakhir (Gambar 3), diskusi berjalan dengan sangat intens, karena mathlet tersebut seperti permainan. Mathlet terakhir ini didisain untuk mengaitkan konsep Pythagoras dengan konsep lain dalam matematika, yakni bahwa sudut keliling yang menghadapi busur setengah lingkaran akan memiliki besar $90^{\circ}$. Dalam hal ini siswa dipaksa untuk mengaitkan konsep terakhir ini dengan Teorema Pythagoras untuk sampai kepada kesimpulan mengapa luas yang besarnya sama dicapai ketika titik merah diletakkan pada lingkarann. Sebagai hasil dari perlakuan yang diberikan, prestasi belajar yang dicapai siswa pada siklus ini adalah 71,2, melebih SKM 68. Namun demikian, penelitian baru berhasil meningkatkan ketuntasan kelas ke tingkat $67.7 \%$, masih belum berhasil mencapai ketuntasan kelas yang dipersyaratkan yakni $70 \%$. Namun jika dibandingkan dengan ketuntasan kelas sebelumnya, penelitian ini telah berhasil meningkatkan ketuntasan kelas 
tersebut.Disamping itu, dari data yang diperoleh melalui kuesioner keterlibatan siswa dan kebermaknaan mathlet, ternyata penggunaan mathlet dalam pembelajaran matematika membantu siswa dalam memahami konsep-konsep yang dipelajari dan melibatkan siswa dalam pembelajaran. Hal ini tercermin dari skor yang mereka capai dalam kuesioner, yakni sebesar 27,4 yang berada dalam kategori cukup positif.

\section{SIMPULAN DAN SARAN}

Dari data penelitian yang diperoleh, dapat disimpulkan bahwa pengintegrasian mathlet dalam pembelajaran matematika berhasil meningkatkan motivasi dan prestasi belajar siswa. Hal ini terlihat dari keaktifan siswa selama pembelajaran berlangsung, baik dalam melakukan eksplorasi, eksperimen, maupun dalam diskusi dalam rangkan membangun konsep-konsep yang dipelajari. Sebagai akibat dari tingginya tingkat keteribatan (engagement) ini, prestasi belajar mereka dari siklus I sampai siklus III berhasil ditingkatkan, dengan rincian sebagai berikut. Pada siklus I, prestasi belajar baru sebesar 55,6 yang berhasil ditingkatkan menjadi 63,2 pada siklus II. Pada akhir siklus III prestasi ini meningkat lagi menjadi 71,2 dengan meminimalisasi berbagai kendala yang dihadapi sebelumnya. Pembelajaran dengan bantuan mathlet juga disenangi siswa yang terbukti dari hasil angket yang diperoleh yakni sebesar 27,4 yang berada pada kategori cukup positif.

Berdasarkan pada hasil penelitian yang diperoleh di atas, kami menyarankan agar dalam pembelajaran matematika guru senantiasa melibatkan siswa secara aktif. Salah satu cara yang bisa digunakan dalam meningkatkan keterlibatan siswa dalam pembelajaran adalah dengan membuat pelajaran tersebut menarik. Penggunaan mathlet dalam pembelajaran merupakan salah satu cara untuk membuat pembelajaran matematika menjadi menarik dan untuk membuat pembelajaran matematika menjadi eksploratif.
Permendiknas No. 41 telah menekankan tentang Eksplorasi, Elaborasi, dan Konfirmasi dalam pembelajaran matematika, namun dalam implementasinya proses pembelajaran yang EEK (Eksplorasi, Elaborasi, dan Konfirmasi) tersebut sangat jarang terlaksana, karena kesulitan mengemas pembelajaran sehingga bersifat EEK. Integrasi mathlet dalam pembelajaran matematika adalah salah satu cara yang bisa digunakan untuk merealisasikan apa yang dituntut oleh permendiknas No. 41 tersebut.

\section{DAFTAR RUJUKAN}

Aksoy, Y., et.all. 2010. The Effect of Geogebra in Conjectures and Proofs. DalamProceedings of The First North American GeoGebra Conference, GeoGebra NA 2010, July 27-28, 2010. (h/m. 190-195). NY: Ithaca College.

Anderson, et.all. 2001. A taxonomy for learning, teaching, and assessing: $A$ revision of Bloom's Taxonomy of Educational Objectives. New York: Longman.

Bosse, M.J., et.all. 2011. Translation Among Mathematical Representation: Teacher Beliefs and Practice. International Journal for Mathematics and Learning (Online http://cimt.ac.uk/journal/default.htm, diakses 14 Februari 2012).

Cengel, M. \& Karadag, Z. 2010. GeoGebra and Process Oriented Assessment: A Potential for Sea Level Change. Dalam Proceedings of The First North American GeoGebra Conference, GeoGebraNA 2010, July 27-28, 2010. (hlm. 136-146). NY: Ithaca College.

Depdiknas. 2004. Kurikulum 2004 Sekolah Menengah Pertama (SMP). Pedoman Khusus Pengembangan Silabus Berbasis Kompetensi SMP Mata Pelajaran Matematika. Jakarta: 
Direktorat Jenderal Pendidikan Dasar dan Menengah.

Hudojo, H. 2003. Pengembangan Kurikulum dan Pembelajaran Matematika. Malang: UM Press.

Ruseffendi, E.T. 1998. Dasar-Dasar Matematika Modern untuk Guru, Edisi Ketiga. Bandung: Tarsito.

Silverman, L.K. 2002. Upside-Down Briliance: The Visual-Spatial Learner.

Denver: DeLeon

Suwarsono, 1998. Peranan Strategi Visual dalam Pembelajaran Matematika.
Makalah disampaikan dalam Seminar Nasional "Pendidikan Matematika dalam Era Globalisasi" yang diselenggarakan oleh Program Pasca Sarjana IKIP Malang 4 April 1998.

10.Stojanovska, L.F. \& Stojanovski, V. 2010. GeoGebra in The College Classroom:Multiple Representations. Dalam Proceedings of The First North AmericanGeoGebra Conference, GeoGebra-NA 2010, July 27-28, 2010. (h/m. 147-153). NY: Ithaca College. 